\title{
Using Modern Educational Technologies in a Law School (Based on Regional Experience)
}

\author{
Marina Aleksandrovna Cherevko ${ }^{1 *}$, Nina Aleksandrovna Makuha ${ }^{2}$, Tatyana Sergeevna \\ Vershinina $^{3}$, Yuliana Vladimirovna Akhmetshina ${ }^{4}$, and Vera Aleksandrovna Yukhnova ${ }^{5}$ \\ ${ }^{1}$ Federal State Budgetary Educational Institution of Higher Education "Far East Branch of the Russian \\ State University of Justice", Advanced Training of Judges and Civil Servants Department, \\ Khabarovsk, Russia \\ ${ }^{2}$ Federal State Budgetary Educational Institution of Higher Education "Far East Branch of the Russian \\ State University of Justice”, General Education Disciplines Department, Khabarovsk, Russia \\ ${ }^{3}$ Federal State Budgetary Educational Institution of Higher Education "Far East State Medical \\ University", Nursing Department, Khabarovsk, Russia \\ ${ }^{4}$ Federal State Budgetary Educational Institution of Higher Education "Far East Branch of the Russian \\ State University of Justice”, Primary Education Department, Khabarovsk, Russia \\ ${ }^{5}$ Federal State Budgetary Educational Institution of Higher Education "Far East Branch of the Russian \\ State University of Justice", Training for the Judicial System Department, Khabarovsk, Russia
}

\begin{abstract}
This article illustrates the regional experience of using modern educational technologies in the Far East branch of the Russian State University of Justice. Presented is the practice of using real-life practical situations within case-methods included in the educational process and aimed at the formation of students' practical skills by means of achieving personal success. This article considers the role and influence of the business games method on the formation of personal and professional competence in students applying for Legal Studies and studying History of State and Law and Foreign Language courses. Designing a modern lecture in accordance with Kolb's Learning Cycle is presented in terms of increasing its efficiency means shifting the emphasis in the lecture material structuring and transitioning to a new format from memorization to acquiring lecture material.
\end{abstract}

Keywords: interactive learning, competency-based approach, case method, business game, "Kolb's Cycle"

\section{Introduction}

The modern educational process is focused on training experts who can adapt to everchanging living conditions, that are capable of independently acquiring necessary skills and applying them in practice. This is manifested in the close behavioral and emotional interdependence between the teacher and students [1]. This educational format promotes productive cooperation by means of exchanging thoughts between students in the group which, in turn, leads to the development of the team's "common sense" [2]. That said, the

\footnotetext{
* Corresponding author: bugoenko@yandex.ru
} 
organization of the educational process at all levels presupposes the use, to a greater extent, of traditional educational methods based on a one-way communication approach to forming knowledge and skills. Consequently, the transition from traditional educational methods to modern technologies enriched with innovative approaches and teaching methods is beyond doubt [3].

\section{Methods}

\subsection{The case-study method}

Analyzing educational technologies actively used in the Far East branch of the Russian State University of Justice, Khabarovsk (FEB RSUJ), it is necessary to focus on the case method. The case method includes specially prepared training materials and special technology of using these materials in the educational process [4]. In turn, T. Kovalchuk and R. Vishnyakov note that the case technology is a combination of such methods as the case method; case study; the method of situational analysis; the incident method; and the analysis of business situations. The authors believe a key common feature for all methods is so-called "problemsituation", which is subjected to in-depth analysis from the position of either determining the problem or searching and validating optimal/possible solutions for it [5]. Our experience shows that the educational process based on the use of case methods is organized in a way that includes the cognition of all students from the said group without exception.

In the Far East branch of the Russian State University of Justice, "Legal Studies" undergraduates of the first year of study actively test various types of case technologies within the "Interactive Teaching Methods" discipline. Taking into account the formation of pedagogical competence within this discipline, undergraduates are welcome to use the following case types:

- undergraduates develop practical cases taking into account their personal practical experience; the case description is accompanied by specific names, dates, and geography; tasks are created based on the real judicial practice. As noted, the purpose of such a case is the experience acquisition, the development of skills and behaviors (decision-making), and knowledge consolidation [6];

- training cases are based mainly on the design of step-by-step professional tasks and functions implementation (the task structure is focused on the formation of skills in drafting statements of claim, objections, petitions, and other procedural documents);

- research cases focused on the formation of methodological thinking and obtaining new scientific situational knowledge, as well as a scientific approach to resolving the proposed contradiction. As a rule, the assignment analysis is accompanied by the analysis of scientific comments on legislation, the study of scientific articles, thesis papers, and monographs.

It should be noted that when using this method, the role of the teacher is modified. The teacher stops being the central figure in the class and can only regulate the educational process and deal with its general organization. The teacher prepares tasks necessary for the process of studying in advance and formulates questions and discussion topics for the group to work on. He can also give advice and control the time and order of implementation of the study plan [7].

To determine the relevance of interactive forms of education in the FEB RSUJ, the authors of this article conducted a pilot sociological survey with the main objective: "List interactive teaching methods that are used in your classes at the university". Students studying in the FEB RSUJ, Khabarovsk, ("Legal Studies" training program, internal study mode ( $=203)$ ) have put together an empirical base for the survey. The type of population sampling is quotabased (field of training, form of training, location), the process of selecting respondents is 
random. Studies have illustrated the following situation: $46 \%$ of respondents pointed to the business game method; $23 \%$ of students (mainly graduate students and undergraduates) pointed to methods for solving specific situations (case method) - it is in the senior years that the list of specialized disciplines increases, with a large volume of practical material; $10 \%$ of the respondents pointed to the brainstorming method; $21 \%$ of the respondents indicated the lack of interactive methods in the process of obtaining a higher legal education.

\subsection{Business game method}

Empirical data have shown that the business game method ( $46 \%$ of respondents) is known better among the students and is a top-requested one by them. Among the many disciplines in the curriculum of the "Legal Studies" training program in the FEB RSUJ, the "History of State and Law" discipline has a special place, as it closely reflects real life outside the university. The business game, as educational technology, is a purposefully constructed model of a real process, simulating professional activity and aimed at the formation and consolidation of professional skills and abilities [8].

Educational business games can be very diverse in terms of organizational structure, didactic goals, and content features. Within the educational game, such personal qualities as responsibility, discipline, a sense of duty, and the ability to interact with the team are actively manifested [9]. Studies have shown that it is very difficult to stimulate a sustained and longterm interest in learning among first-year students. In this regard, game methods help students in adapting to the educational process. So, taking into account the specifics of the discipline, model games, imitation games, discussion games, court games, theatre games ("acting out scenes", "playing roles"), didactic games, business games, illustrative games can be distinguished.[10] All these games are designed for 15 to 30 participants (the number corresponds to a basic full-stacked training group) are played in one lesson one and a half hours long, and, as a rule, do not require additional props and long preparation [11].

\subsection{Kolb's Cycle based lecture}

FEB RSUJ implements a smooth transition to a new lecture format using the Kolb's Cycle method, due to the fact that the teacher has to show increased attention to the assimilation of information by students, not memorization. Each of these stages represents a complex process that is interrelated with the goals and objectives of a particular lecture. In general, the essence of the teaching methodology, built in accordance with the Kolb's Cycle, consists of an emphasis shift in the construction of the lecture material. It is known that the existing method of preparing and conducting a lecture presupposes an existence of a general structural framework applicable to any lecture. In the authors' opinion, this approach ensures that the lecture has to convey the information to students who need to know it in accordance with the curriculum. At the same time, modern lecture development methods should be distinguished by creativity, the motivational potential for further cognitive activity among students which largely depends on the ability of the teacher to build a practice-oriented approach to teaching. In this regard, the methodology of the lecture built on the basis of Kolb's Cycle creates a bridge from the educational situation to the professional situation, and therefore to the formation of appropriate expertise [3]. The process of improving professional skills is never complete. It can be represented by an endless spiral of competence development (Figure 1). 


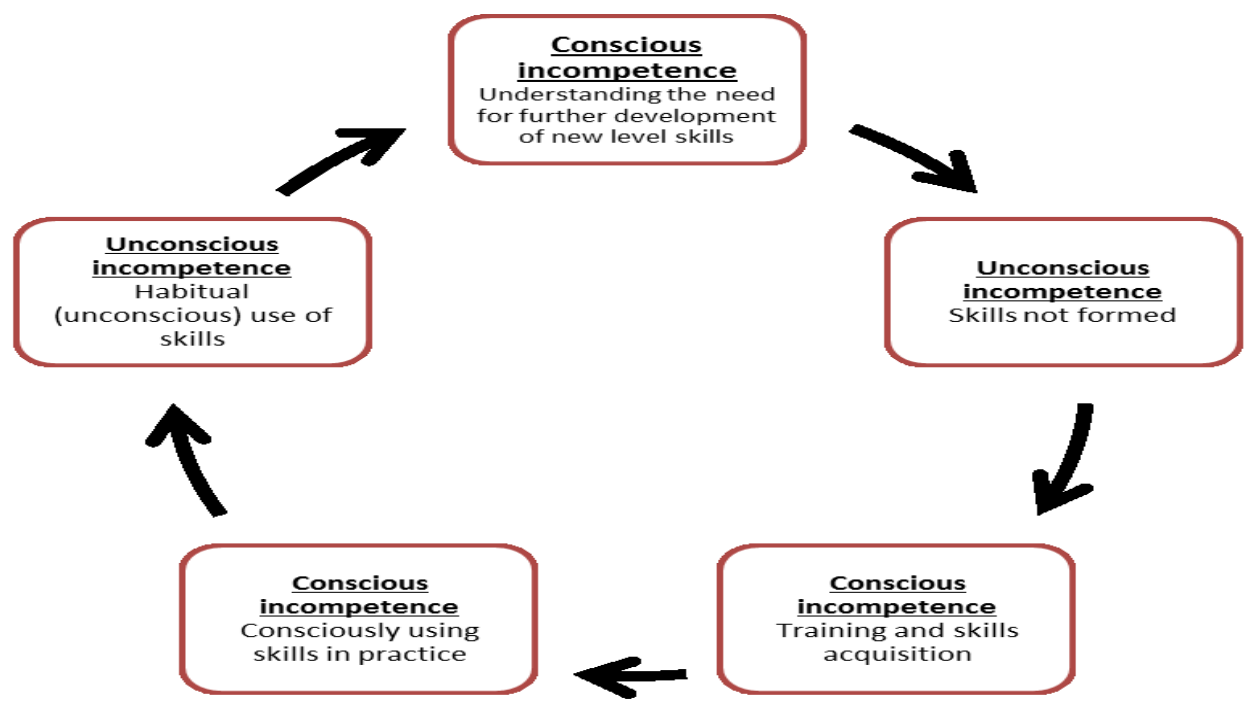

Fig. 1. The spiral of competence development.

\section{Results}

As an example, let us consider the experience of using Kolb's Cycle in the process of studying the "Political Science" discipline by students of the "Legal Studies" training program.

The practical part of the discipline's study is writing a research paper on the chosen topic. The result is a lecture/conference where the student has to defend his or her research work. Thus, students gain specific experience in the process of preparing and defending their research work. To carry out a comparative efficiency analysis of the traditional approach to this kind of class built according to Kolb's Cycle, the lecture/conference was held separately in each group.

In the case presented by the authors of this article, based on the data obtained by the teacher at the second stage of the training process, an overview lecture for the entire course was presented to the students that covered the entire range of problems specified by the students. A similarly constructed educational process allows students to consolidate their knowledge smoothly. At the same time, the teacher took into account the fact that the overview lecture is a part of the final training stage, which means that students now have a certain set of knowledge. Therefore, before proceeding to the overview lecture, the teacher has tested the students' knowledge on one of the basic topics, namely: "The social-political system, political relations, and processes". At the same time, the teacher's task was to form a creative approach to this issue.

Based on this analysis, authors can conclude that using the methodology of modern lectures based on the technology proposed by J. Kolb allows us to improve the quality of knowledge and to form the necessary knowledge, skills, and abilities in students.

\section{Conclusion}

The modern context in which higher education functions always changes shaping both opportunities and challenges in terms of strategy for fulfilling its role in learning and teaching. An essential basis, as practice shows, in the application of modern educational technologies is the use of creative, non-standard approaches to the organization of the 
educational process. It is the initial value in working with students and contributes to the formation of an integrated interdisciplinary approach and enriches modern pedagogical practice [12]. The use of new forms and methods in the learning process involves the rejection of putting pressure on students and contributes to the formation of critical thinking in both teachers and students. As rightly noted by I.V. Leonteva Critical thinking is a systematic phenomenon that encompasses a sequence of algorithmic actions and operations and manifests itself in understanding the structure of objects and phenomena, the relationships between them; the ability to identify the most significant among them; understanding the role of each structural component of activity, behavior, and their impact on the student activity development [13]. To date, the university has created all the conditions for using modern educational technologies. At the same time, it is important to understand that modern teaching technologies should not be used by the teacher just for the sake of using them in the educational process.

\section{References}

1. R. Lersch, Lernende Schule 58, 13 (2002)

2. K. Berkel, Konflikttraining, Konflikte verstehen, analysieren, bewältigen (Verlag, 2010)

3. I.M. Gritsevskaya and E.V Shevyakov, Bul. Krasnoyarsk State Pedagog. Univ. named after V.P. Astafiev 48-56 (2019)

4. S.Y. Gruzkova and A.R. Kamaleeva, Rus. J. Educ. and Psy. 6 (2016) http://dx.doi.org/10.12731/2218-7405-2013-6-24

5. T. Kovalchuk and R. Vishnyakov. Людинознавчі студії. Серія "Педагогіка" 8/40, 27-42 (2019) https://doi.org/10.24919/2413-2039.8/40.164392

6. S. Puri, Innov. in Ed. and Teaching Int. 9(3), 159-164 (2020)

7. S.N. Alyamkin, Sc. and Ed. World 1(1) (2015)

8. S.V. Tereshchenko and M.K. Zagorskaya, Evropeiskii opyt primeneniya metoda keisov $\mathrm{v}$ obuchenii studentov predprinimatelstvu [European Experience of Using the Case Method in Teaching Entrepreneurship to Students] Accessed on: March 16, 2021. [Online]. Available:

https://www.researchgate.net/publication/341435304_Evropejskij_opyt_primenenia_m etoda_kejsov_v_obucenii_studentov_predprinimatelstvu

9. M.V. Nikolaev and N.V. Mankova, Sc., Cult., Ed. World 6(67), 174 - 178 (2017)

10. R. Krinits, IALLT J. the Language of Ed. Technol. 5, 14-22 (2019)

11. G. Cabaleiro-Cerviño, GiST Ed. and Learn. Research J. 20, 155-169 (2020)

12. M. V. Astudillo, Global J. of Human-Soc. Sci. 20(10-G), 51-55 (2020) https://doi.org/10.34257/gjhssgvol20is10pg51

13. I.V. Leontjeva, Збірник наукових праць 32, 29-38 (2019)

https://doi.org/10.28925/2311-2409.2019.32 